\title{
DIE VERHOUDING TUSSEN DIE OU TESTAMENT EN NUWE TESTAMENT HEILSHISTORIES OORWEEG
}

\author{
J G VAN DER WATT
}

\begin{abstract}
The relation between the Old Testament and the New Testament salvation historically considered

The way in which the early Christians approached the Old Testament in the light of the Christ event is first investigated. On theological, soteriological and historical level a strong relationship between the two Testaments was acknowledged. This relationship can be defined further in terms of fulfilment, continuity and discontinuity. As the coming of Christ was soteriologically determinative, the status of modern man in this respect is the same as that of the early Christians. In continuity with the early Christians we today can also read the Old Testament in the light of fulfilment, continuity and discontinuity which characterises the theological, soteriological and historical relationship between the Testaments.
\end{abstract}

\section{Inleiding}

Baker se werk, waarin hy 'n oorsig gee oor die vernaamste moderne pogings om die verhouding tussen die twee Testamente te omskryf, word soos volg aangevoor: "One of the most fundamental questions which has faced theology and the Church in every age and still demands an answer today is whether or not Christianity (sic) also needs an Old Testament to be thrown away as obsolete ... or used occasionally ... or is the Old Testament an essential part of the Christians Bible ...?"')

Hierdie vraag is deur die eeue op verskillende maniere beantwoord.2) Soms is die klem op die Ou Testament los van die Nuwe Testament geplaas $^{3)}$ en soms is al die fokus weer op die Nuwe Testament laat val.4) Vele pogings is ook aangewend om die Ou Testament in die lig van die Nuwe Testament te lees, ${ }^{5}$ soveel so dat die Ou Testament in sommige gevalle gedegradeer is asof dit maar net ' $n$ voorbereidende funksie ten opsigte van die Nuwe Testament sou hê..6) Die kanon en veral die Ou Testament in die kanon word dus deur verskillende interpreteerders wyd uiteenlopend hanteer. Hier word nie verder aandag gegee an die geskiedenis van die debat nie. Die saak self gaan eerder aandag geniet. Dit is tog hermeneuties noodsaaklik dat daar noukeurig oor die verhouding tussen die Testamente nagedink moet word.

In hierdie artikel gaan probeer word om binne 'n heilshistoriese raamwerk 'n sistematiese uiteensetting te gee van hoe die verhouding tussen die twee Testamente moontlik verstaan kan word.7) 
2. 'n Situasie-analise ten opsigte van die gebruik van die Ou Testament in die vroeë kerk soos dit in die Nuwe Testament weerspieël word

Die vroeë Christene het nie in 'n vakuum geleef nie. Hulle het binne 'n bepaalde tradisie-historiese raamwerk gestaan. Daarbenewens is hulle ook met 'n nuwe werklikheid in Christus en alles wat dit behels, gekonfronteer. Dit het hulle belewenis van hulself, hul omgewing en veral hul godsdiens ingrypend beinvloed. Die Ou Testament het nie los van hierdie belewenis gestaan nie, maar het binne die Christene se totale werklikheidservaring ' $n$ bepaalde plek ingeneem. Hierdie integrasie van die Ou Testament in die vroeg-Christelike situasie gaan nou verder aandag geniet. (Let daarop dat die begrip "Ou Testament" in hierdie artikel na die, in daardie stadium nog onvoltooide, "Ou Testament" verwys.)

\subsection{Drie sentrale realiteite}

Veral drie realiteite wat ' $n$ vername plek in die denke van die vroeë Christene ingeneem het, moet hier aandag geniet.

\subsubsection{Die realiteit vạn die geloof in die lewende God}

Daar kan min twyfel bestaan dat die lewende God waarvan die Ou Testament vertel, deur die eerste Christene, meer nog deur Christus self, as die God van die Christendom gesien is . ${ }^{8)}$ Luz beklemtoon dat: "...für die Christen des Neuen Testaments axiomatisch der Gott des Alten Testaments ihr Gott und das Alte Testament ihre heilige Schrift war". ${ }^{\text {9) }}$

Wat veral van belang is, is die oortuiging dat die "goddelike kontinuiteitslyn" wat in die Ou Testament begin het, sy weg deur die Christendom voortsit. Dat die Nuwe Testament dus van dieselfde God as die Ou Testament vertel, is tog in die eerste instansie 'n geloofsuitspraak. ${ }^{10)}$ In geloof is die optrede van Jesus geïnterpreteer en as die aanbreek van die eskatologiese realiteit wat die lewende God reeds in die Ou Testament beloof het, verstaan (vgl Jh 2:22; 12:16; 14:26).

\subsubsection{Die nuwe lewensrealiteit van verloste Christene}

Met die koms, en in die optrede, van Christus het die eskatologiese werklikheid op aarde aangebreek. In Christus is die gelowiges met nuwe realiteite gekonfronteer en het hulle hulself en die wêreld waarin hulle geleef het vanuit die nuwe perspektief gesien. Die Christene was dus Christologies-bepaalde mense (Kol 2:6-7; 3:1-3, 11; Fil 1:20-21; of in 
Johannese terme: Jh 14:6-7; 17:9-11). Die implikasie hiervan was dat die wyse waarop die Christene elke situasie benader het dus Christologies gekleur en bepaald was, en natuurlik ook so hul benadering tot die historiese heilstradisie waarin hulle gestaan het (waarvan die Ou Testament 'n sentrale deel vorm). Dit is daarom verstaanbaar dat die vroeë Christene nie anders as vanuit 'n Christologiese perspektief oor die Ou-Testamentiese gebeure gepraat het nie. ${ }^{11)}$ Die Ou Testament het vir hulle iets van die heerlikheid van die nuwe realiteit waarin hulle gestaan het, verwoord: "...for Christians the Old Testament only has meaning in so far as it refers to Christ and was able to speak in the light of Christ". ${ }^{2)}$

Die boodskap wat Jesus gebring het, spreek van die koninkryk van God, die nuwe lewe en God se eskatologiese werklikheid wat nou deel van die mens se bestaan geword het. Die vroeë Christene was dus ook eskatologies-bepaalde mense. Die gawes en verwagtinge, die nuutheid en vryheid wat God se nuwe era sou bring het onbetwisbaar deel van hul lewenservaring gevorm (Rom 5:1-2 of Ef 1:3,12-14).

Daarbenewens is daar ook die voortdurende teen woordigheid van die Heilige Gees wat die "nuwe realiteit" konstant in die lewens van die Christene 'n lewende ervaring en werklikheid gemaak het (Jh 14: 17-26, 16:13).

Die nuwe christologies-eskatologiese lewensrealiteit van die verloste Christene gedy dus alleen binne die aktiwiteitsfeer van die Heilige Gees.

\subsubsection{Die realiteit van die Ou Testament as bron}

Du Toit sê dat hoewel die grense van die Ou-Testamentiese kanon vir die Christene "...nog geruime tyd vloeibaarder as in die sinagoge gebly het..., is dit duidelik dat die kanon-idee, d.w.s. die aanvaarding van 'n gesaghebbende corpus van Ou-Testamentiese geskrifte, dwarsdeur die Nuwe Testament en daarom ook by die Apostoliese Vaders 'n onaanvegbare werklikheid is". ${ }^{\text {3) }}$

Die eerste Christene het vanuit hul Christusbepaaldheid "terug" gekyk op die Ou Testament en verbande gelê tussen hulle eie situasie en dié van die Ou Testament. Dit het hulle gedoen vanuit die oortuiging dat wat met hulle gebeur het 'n bepaalde "voorspel" in die Ou Testament gehad het. Die Ou Testament is dus vanuit hul bepaalde historiese situasie geïnterpreteer.

\subsubsection{Slotsom: drie realiteite, een werklikheid}

Daar sou gesê kon word dat hierdie drie "realiteite" die basis vorm van 
waaruit die teenwoordigheid en dinamiek van die Ou Testament in die vroeg-Christelike situasie verstaan kan word. Die gemeenskaplike en samebindende "faktor" is God. Tog is die God nie in hulle situasie op presies dieselfde wyse as in die Ou-Testamentiese tyd besig nie. Hulle leef in die eskatologiese era waar Christus bepalend deur die werk van die Heilige Gees betrokke is. As Christene is hulle egter tradisie-histories aan die gebeure van die Ou-Testamentiese era gebind en daarom verleen die Ou Testament aan hulle toegang tot hierdie verlede. Die realiteite van God se teenwoordigheid, hulle eie situasie en hulle kontak met die verlede was vir hulle in een lewenswerklikheid geïntegreer. Vervolgens gaan probeer word om die "integrasie" in breë trekke verduidelikend te sistematiseer.

\subsection{Die integrasie van die "Ou Testament" met die "nuwe lewens- realiteit van die verloste Christene"}

Die Ou Testament is nie bloot belangrik omdat dit deur die vroeë Christene aangehaal word nie (ander boeke is ook deur hulle aangehaal, bv. Henog 1:9 in Judas 15). Die telkense verwysing na die Ou Testament in vroeg-Christelike materiaal weerspieël 'n diepere verweefdheid.

Hier moet veral daarop gelet word dat daar van werklike integrasie van die Ou Testament in die lewende Nuwe-Testamentiese situasie spra$k e$ is. Die Ou Testament moes in die Nuwe-Testamentiese situasie "spreek" en wel in terme van en vanuit die "Christusgebeure". Dit gaan dus nie hier om 'n bloot willekeurige toepassing van die (nog nie afgeslote) Ou Testament op die Christusgebeure nie, maar om 'n tradisie-geskiedkundige voortsetting in die Nuwe Testament van die openbaring wat reeds in die Ou Testament begin het. ${ }^{14)}$ Immers, "Das im 1. Jh. n.Chr. noch 'offene' Alte Testament bildet vielmehr den traditionsgeschichtlichen Mutterboden des Neuen Testaments. Es ist die Wiege, in der die neutestamentliche Heilsverkundigung entstanden ist". ${ }^{15)}$ So was die Ou Testament van die begin van die Christelike tradisie af as "christliche Offenbarungsurkunde" gelees ${ }^{16)}$ en dus binne Christologiese perspektief geplaas en verstaan. Die verweefdheid tussen Ou en Nuwe Testament was onmiskenbaar.

Hierdie verweefdheid sou op die volgende wyse gesistematiseer kon word. Daar sal allereers op drie belangrike verbande gewys word waarvolgens die Ou-Testamentiese materiaal in die vroeg-Christelike situasie geintegreer is. Hierdie verbande is naamlik die teologiese, soteriologiese en die historiese. ${ }^{17}$ 


\subsubsection{Die teologiese verband}

Hierdie verband wat daar tussen die Ou-Testamentiese materiaal en die vroeg-Christelike situasie gesien is, hang nou saam met die geloof dat dieselfde God in albei situasies werksaam is. Daarom kom daar teologiese momente wat eie aan God is in die Nuwe Testament voor om so die geïntegreerdheid tussen die twee situasies te verwoord. God is funksioneel in die Ou- én Nuwe-Testamentiese gebeure teenwoordig.

Met enkele voorbeelde sal volstaan word. Die wyse waarop Jesus byvoorbeeld in Kolossense 1:15-20 of Johannes 1:1-5 beskryf word, is in terme van kwaliteite en optrede wat eintlik net van God self waar kan wees. Daarom word Jesus die beeld van God genoem. Die tipies-teologiese funksies (skepping en verlossing) van die God van die Ou Testament word in die Nuwe Testament aan Jesus toegeskryf. Ook in Johannes word soortgelyke motiewe aangetref (bv Joh 5:19-30). Immers, in die optrede van Jesus word die Vader gesien en wie Jesus aanvaar, aanvaar die Vader (Joh 8:18-19; 10:30).

Nie alleen wat heerlikheid en status betref nie, maar ook ten opsigte van funksionele optredes "bind" God self die twee Testamente "aanmekaar".

\subsubsection{Die soteriologiese verband}

As Johannes die doel van sy evangelie beskryf, stel hy onder andere die soteriologiese aspek voorop (20:31). Petrus praat ook van die ' 'nuwe lewe" (1 Pet 1:3-4) en Paulus van die geregtigheid wat 'n mens sal laat "lewe" (Rom 1:17). Dit is die lewende God van die Ou Testament wat in Christus die eskatologiese lewe op aarde 'n moontlikheid gemaak het (1 Tes 1:9-10 en 5:9-10; Joh 5:26 en 6:57).

Dit gaan in albei Testamente oor die heil wat dieselfde God bring. Daarom is dit moontlik om die heil waarvan die Nuwe Testament praat in die lig van die $\mathrm{Ou}$-Testamentiese heilsoptrede te verstaan, hoewel erken moet word dat die heilsgebeure in Christus sy kulminasiepunt bereik het. As daar in terme van 'n kulminasiepunt gepraat word, word natuurlik geïmpliseer dat daar van een proses sprake is. Juis omdat die Ou Testament en die Nuwe Testament deel van een heilsproses is, kan Christus die openbaring van God se geheimenis en so die heilskulminasie daarvan wees (Ef 3:2-6; Kol 1:26-29). Westermann sê dan inderdaad dat die reddende en seënende God wat die mens tot reaksie roep (verlossing), as kern van die Ou-Testamentiese teologie gesien kan word en dat dit bepaald so in die Nuwe Testament voortgesit word. ${ }^{18)}$

Die soteriologiese gegewens van sowel die Ou as die Nuwe Testa- 
ment is van mekaar afhanklik wat sowel die sinvolheid as die begrip daarvan betref.

\subsubsection{Die historiese verband}

'n Derde verband wat tussen die Testamente bestaan, vind uitdrukking in die besef dat die geskiedenis wat in die Ou Testament begin het, voortsetting in die Nuwe Testament vind. ${ }^{19)}$ Die gebeure van die Ou en Nuwe Testament moet dus as deel van een historiese proses gesien word. So word die Christene byvoorbeeld deur Johannes, Paulus en die Hebreërskrywer gesien as die voortgang van die ware Israel. Riekert stel dit mooi: "There was only one process in the development of the tradition which comprises both Old and New Testaments". ${ }^{20)}$ Daarom is Christus as die kulminasie en sentrum van die geskiedenis gesien wat in Eden begin het en vandag steeds voortgaan. ${ }^{211}$

\subsection{Die eienskappe van die drie verbande waarvolgens die Ou- en Nuwe-Testamentiese materiaal ineenvloei}

God tree in die Ou Testament nie in alle opsigte presies so op soos in die Nuwe Testament nie. Dit het Marcion reeds opgemerk. Maar tog is dit dieselfde God. Ook die redding vind nie op dieselfde wyse in die twee Testamente plaas nie, hoewel daar tog van dieselfde saak sprake is. Niemand sou cok wou beweer dat die geskiedenis die selfde gebly het voor en na die koms van Jesus nie, hoewel dit deel van dieselfde geskiedkundige proses is.

Die integrasie van die Ou-Testamentiese materiaal met die vroegChristelike situasie het dus op teologiese, soteriologiese en historiese vlak nie sommer direk en ongenuanseerd plaasgevind nie. "Lyne" is nie sommer "reguit" getrek nie. Daar kan sekere eienskappe aangedui word wat die toepassing en funksionering van hierdie drie verbande onder andere bepaal en omlyn het. (Tussen hakies moet genoem word dat dit nie hier om 'n tipe skematisme handel nie, maar om 'n wyse waarop die vroeë Christene moontlik kon verstaan hoe die Ou Testament met hulle eie situasie verband gehou het. Die eienskappe is ook nie op alle Ou-Testamentiese materiaal op dieselfde wyse en met dieselfde intensiteit van toepassing nie. In sommige boeke van die Ou Testament is daar sterker sprake van byvoorbeeld vervulling as in ander gevalle. ' $n$ Tipe "pannekoekbenadering" waarvolgens alle Ou-Testamentiese materiaal op dieselfde wyse hanteer moet word, word dus nie hier voorgestaan nie. Dit mag ook wees dat net een van die eienskappe van 'n bepaalde OuTestamentiese gedeelte mag geld.) 


\subsubsection{Die eienskap van vervulling}

Westermann noem belofte en vervulling "die entscheidende Beziehung" wanneer dit by die verhouding tussen die Ou en Nuwe Testament kom. ${ }^{22)}$ Die Ou Testament skep die verwagting dat God iets nuuts gaan doen as vervulling van dit wat vooraf gaan: "The Old Testament can only be read as a book of ever increasing anticipation". ${ }^{23)}$ Von Rad gaan verder en toon aan dat die Ou Testament eintlik op 'n vraagteken eindig. Vervulling kon op verskillende wyses kom, of miskien glad nie. Dit is egter alleen as die heilsgebeurtenis in Jesus plaasvind en Hy aan sy dissipels illustreer hoe die Skrifte in Hom vervul word (bv Lk 24:26-27 en 24:44-46), dat die OuTestamentiese verwagting in perspektief gestel word. Dan word die Nuwe-Testamentiese gebeure onlosmaaklik met die Ou Testament gekoppel en word die vraagteken van die Ou Testament in die Nuwe Testament beantwoord.

Vanuit Nuwe-Testamentiese perspektief is sake waaroor in die Ou Testament geprofeteer is, wat geïmpliseer en waaroor gespekuleer is, in Christus vervul. Daarom dui geleerdes daarop dat 'n Christologiese verklaringsraamwerk na alle waarskynlikheid reeds van die vroegste gemeente af deel van die nadenke oor die Ou Testament uitgemaak het. Hierdie verklaringswyse, meen Schelkle, kon selfs na Jesus self teruggegaan het. ${ }^{24)}$ Hoe dit ook al sy, hierdie benadering word onbetwisbaar direk en indirek in die Nuwe Testament weerspieël (vgl maar net enkele voorbeelde: Mt 1:23; 2:6, 18; Hebreërs; Jh 12:13-16, 38-40; Kol 1:26-28). In die lig hienvan sê Zimmerli ook dat "in Christ the Old Testament is at an end". ${ }^{25)}$ Daarmee sê hy nie dat die Ou Testament alle betekenis verloor het nie. Die Ou Testament se "eie wêreld is egter in die groter wêreld van vervulling opgeneem en moet dus van daaruit verstaan word. ${ }^{26)} \mathrm{Her}$ meneuties was dit eenvoudig nie meer vir die vroeë Christene moontlik om die Ou Testament te lees as of daar niks gebeur het nie. Tussen hulle en die Ou Testament het Christus gestaan; Christus wat hulself én die OuTestamentiese gebeure in 'n nuwe perspektief laat staan het.

Daar is reeds genoem dat die eienskap van vervulling op 'n funksionele wyse die teologiese, soteriologiese en historiese verbande tussen die Ou en die Nuwe Testament omskryf en omlyn. Wat die teologiese verband betref, praat Dodd van 'n "organic outgrowth or ripening of the original thought". ${ }^{27)}$ Van Zyl beklemtoon byvoorbeeld dat sake soos die kultuswette ook nie sommer oorboord gegooi word nie, maar dat dit "volkomer" gemaak word deur die offer van Christus. ${ }^{28)}$ Sake soos die verbond, die eskatologiese koms van die dag van die Here, die ware aard van die Koninkryk van God en so meer - sake wat almal reeds in die Ou Testament beklemtoon word - word in die Nuwe Testament vanuit die 
perspektief van Christus nuut en "voller" geïnterpreteer.

Wat die soteriologie betref, is daar reeds na Christus verwys as die volkome vervuller van die heilsplan van God. Die soteriologiese verband tussen die Ou en Nuwe Testament het alleen sin in die lig van die vervullende heilswerk van Christus.

Wat die historiese verband betref, beweer Eichrodt byvoorbeeld dat daar doelgerigte beweging in die Ou-Testamentiese geskiedenis is, en sê: "This movement does not come to rest until the manifestation of Christ, in whom the noblest powers of the Old Testament find their fulfilment". ${ }^{29)}$ Reeds in byvoorbeeld Hebreërs 1:1 word die noot van historiese vervulling geslaan wat verder in die boek bly voortklink. Die gang van die geskiedenis het uitgeloop in ' $n$ volmaakter era, met die volmaakte offer en Hoëpriester. Hierdie gedagte vind weerklank in die res van die Nuwe Testament (bv Rom 9:11; Kol 1:26-28; Lk 21:25-33; Op 4:1 en verder).

\subsubsection{Die eienskap van kontinuïteit}

Geen radikale of finale breuk is deur die Christene aangevoel tussen die Ou-Testamentiese gebeure en hulle eie situasie nie. Daar was'n tradisiehistoriese ontwikkeling wat met die Ou-Testamentiese gebeure begin en soos 'n rivier in die Nuwe Testament uitgevloei het. Die basiese kontinuiteit tussen die twee Testamente kan nie ontken word nie.

So word die waarborg van kontinuilteit op teologiese vlak veral in die optrede van Jesus gevind. Hy is die beeld van God (Kol 1:15) en as sodanig verbeeld Hy die funksies van God op aarde (Jh 5:21-23 of Kol 1:15-20). So word die openbaring van God gekontinueer (Jh 1:1-18). Christus vergewe die sonde (iets wat net God kan doen), gee lewe, oordeel, breek die mag van Satan en manifesteer Homself so as die voortsetting van God se teenwoordigheid op aarde. Daarmee word die teenwoordigheid van God die Vader self nie uitgeskakel nie. God die Vader is en bly self ook in die Nuwe Testament aktief teenwoordig. Dit impliseer natuurlik dat in die uitleg van die een Testament die "..Stimme des anderen daurend mitgehort wird". ${ }^{30)}$

Cullmann stel die saak binne sy bepaalde teologiese benadering so: "Das Prinzip der Kontinuität, das für alle Heilsgeschichte charakteristisch ist, personifiziert sich hier, am Hohepunkt alien Geschehens, in der PersonJesu Christi...".31) Vanuit sy heilshistoriese benadering is Jesus die punt waar die ganse geskiedenis saamvloei. Hierdie geskiedenis is primêr heilsgeskiedenis. In Christus word die heil met 'n nuwe impetus verder gevoer. So waarborg Jesus die kontinuiteit tussen die twee Testamente op soteriologiese vlak.

Wat die historiese verband betref kan by Bright se stelling aangesluit 
word: "...the continuity lies in the obvious fact that Christianity is historically a development out of Judaism ... the Old Testament is an integral part of that history of redemption which is brought for completion in Jesus Christ". ${ }^{32}$ Enkele voorbeelde van hoe die vroeë Christene hulle historiese kontinuiteit met die Ou-Testamentiese gebeure beleef het, blyk uit die geslagsregisters (Mt 1 ) of uit die verklaring dat Jesus in die koninklike lyn van Dawid staan (Rom 1:3).

\subsubsection{Die eienskap van diskontinuiiteit}

"The Old Testament ... stands in discontinuity with the New because it speaks a B.C. word, not a A.D. word". ${ }^{33)}$ Met hierdie woorde is die kwessie van diskontinuilteit aangeroer. Christus het die eras kom verander, maar ook kom vervang (bv Rom 5:12-21; Jh 6). Op teologiese vlak het daar in vele opsigte 'n herinterpretasie of betekenisverskuiwing ten opsigte van sekere sake gekom. Die nasionale Israel verander na die geestelike gemeenskap van gelowiges, God se verbond is nie meer nasionaal bepaald nie, God se beeld het sigbaar geword, en so meer.

Ook wat die soteriologiese verband betref, is diskontinuiteit ter sprake. Met apologie aan Bultmann kan inderdaad gesê word dat Christus God se soteriologiese antwoord op die heilsroep van die Ou Testament is. ${ }^{34)}$ Daarmee het sekere aksente rondom die heilsverkryging, die rol van diekultus en die Wet, die eskatologiese verwagting van die Jode en so meer, verander. Christus, die tweede Adam, maak nou die mense vry.

$\mathrm{Na}$ die koms van Jesus sal die geskiedenis ook nooit weer dieselfde wees nie. Die ou aeon vervaag in die lig van die nuwe. Die koninkryk van God is nou daar. Nou is die Christen net 'n bywoner, op pad na iets beter. Die oue het geëindig en die nuwe het begin. Daarmee word die OuTestamentiese geskiedenis nie negeer nie, maar soos Van Zyl sê, eenvoudig volkomer gemaak. ${ }^{35)}$

In die lig van bogenoemde moet daar tog op enkele sake gelet word.

(a) Die onderlinge verbande moet nie in isolasie van mekaar gesien word nie. Dit beteken byvoorbeeld dat die teologiese verband die historiese moontlik maak. God tree immers in die geskiedenis op. Sonder die historiese verband sou die teologiese ook weer onbekend gebly het, want God openbaar homself in die geskiedenis.

(b) Die drie eienskappe van die verbande wat die Ou en Nuwe Testament 
omlyn, moet ook in samehang gesien word. Juis die feit dat daar vervulling van elemente is, beteken dat daar 'n bepaalde kontinuiteit, maar ook ' $n$ bepaalde diskontinuiteit bestaan. Tog moet al drie die eienskappe (of verbande) nie elke keer in elke teks in die Ou Testament gesoek word nie. Alleen 'n enkele eienskap (verband) mag per geleentheid in 'n spesifieke geval gerealiseer word.

(c) Die drie verbande tussen die Ou en Nuwe Testament moet altyd in verhouding tot die drie eienskappe wat die verbande omlyn, gelees word. Hierdie verhouding word egter bepaal en gerig deur die Christologieseskatologiese werklikheid waarin die vroeë Christene geleef het.

\subsection{Die plek van interpretasiewyses in die geïntegreerde situasie van die vroeë kerk}

Tot dusver is nog niks oor die funksionele plek van interpretasiemetodes soos tipologie of allegorie gesê nie. Dit is veral die vrye, buite-kontekstuele wyse (in moderne eksegetiese terme) waarop die Nuwe-Testamentiese skrywers met die Ou Testament omgegaan het, wat opval.

Dit is belangrik om daarop te let dat die vroeë Christene nie sonder voorveronderstellings met metodes soos tipologie of allegorie na die destyds beskikbare Ou-Testamentiese materiaal gegaan en dit met ' $n$ "groot wetenskaplike openheid" geïnterpreteer het nie. Vanuit hulle Christologies-eskatologiese bepaaldheid het die Ou Testament op 'n bepaalde wyse hul nuutgevonde realiteit in Christus belig. ${ }^{36)}$ Die metodes was instrumenteel daarin dat die Ou Testament wel in hulle situasie gespreek en hulle so gehelp het om die Ou Testament sinvol te verstaan en hermeneuties in hul situasie te integreer. ${ }^{37)}$

Die funksionering van enkele metodes sal net kortliks geillustreer word. Tipologie as ' $n$ bekende metode van uitleg, is veral relevant as dit by eienskappe van kontinuiteit en diskontinuiteit kom. "The Old Testament type not only corresponds to the new-age reality but also stands in antithesis to it" ${ }^{38)}$

As Paulus Jesus tipologies met Adam vergelyk, probeer hy daarmee aandui dat Jesus vanweë sy persoon 'n beter en groter era as Adam verteenwoordig. Adam of Abraham het sekerlik nie bloot op die aarde geleef sodat hulle by die geboorte van Christus as tipes van Christus kon dien nie. Met die koms van Christus het daar vanuit teologiese refleksie bepaalde patrone van ooreenstemming na vore getree wat inderdaad die intensiteitstoename van Adam tot Christus mooi tot uitdrukking gebring het. Hierdie feit is met behulp van tipologie onder woorde gebring. Tipologie wys dus op die ooreenkomste, maar ook op die verskille, tussen groot 
figure uit die geskiedenis en Christus: “...typology is never mere repetition but is always combined with a change of key in which some aspects of the type are not carried over and some are intensified". ${ }^{39)}$

Struktuur-analogie is ook deur die Nuwe-Testamentiese skrywers as metode gebruik. Die brief van Judas bied 'n goeie voorbeeld. In vers 5 word die strawwe genoem wat "as waarskuwing vir almal" ( $v 7)$ dien. Die waarskuwing verwys na die Christelike era op grond van die feit dat die $\mathrm{Ou}$ en Nuwe Testament van dieselfde God praat. Alleen vanweë die Christelike werklikhede waarin daar teologiese en ander verbande funksioneer kon daar struktuur-analogies te werk gegaan word. Die metode as sodanig bied dus uitdrukking aan die teologiese werklikheid wat reeds bestaan.

Die metodes was dus funksioneel in die mate waarin dit uitdrukking kon gee aan die manier waarop die vroegste Christene hul eie bepaaldheid en van daaruit die verbande met die Ou Testament beleef het. Die metodes was alleen 'n middel tot 'n doel en nie die doel op sigself nie. Vir die vroeg-Christelike skrywers was die interpretasietegnieke van die Judaïsme voldoende solank hulle aan hul beleweniswerklikheid reg kon laat geskied. Dit blyk ook uit Vorster se bewering: "The difference between the use of the Old Testament in the New and in extra-canonical contemporary Jewish sources is not to be found in the techniques of application but at a theological level ... Old Testament material is used in a reinterpreted form and actualized to authorize particular views". ${ }^{40)} \mathrm{Nie}$ die metodes van interpretasie nie, maar die teologiese en ander verbande was bepalend.

\subsection{Samevatting van die situasie in die vroeë kerk}

Uit die voorafgaande skema is dit duidelik dat die Ou Testament binne 'n totale konteks opgeneem is. Alles word omsluit deur die geloof dat een en dieselfde God in sowel die Ou as die Nuwe Testament optree. Die "lewenskonteks" was gekenmerk deur die Christologies-eskatologiespneumatologiese bepaaldheid van die vroeë Christene. Hierdie "bepaaldheid" het tot stand gekom as gevolg van die historiese optrede en leer van Christus wat op gekontroleerde wyse deur die apostels bewaar is. Hierdie Christusgebeure het egter nie los gestaan van die Ou-Testamentiese gebeure nie. Die Christusgebeure kon eintlik eers in die regte perspektief gestel word indien die verband tussen dié gebeure en die Ou Testament aangetoon is. Dit is gerealiseer deur onder andere die verbande (teologies, soteriologies en histories) in terme van die elemente (vervulling, kontinuiteit en diskontinuiteit) te omskryf. Bepaalde metodes is gebruik om dit godsdienstig te ontsluit, byvoorbeeld tipologie, allegorie en struktuur- 
analogie. Op die wyse het die Ou Testament as 'n lewende deel van die Christusgebeure gefunksioneer en derhalwe neerslag in die Nuwe Testament gevind.

Skematies kan dit so voorgestel word:

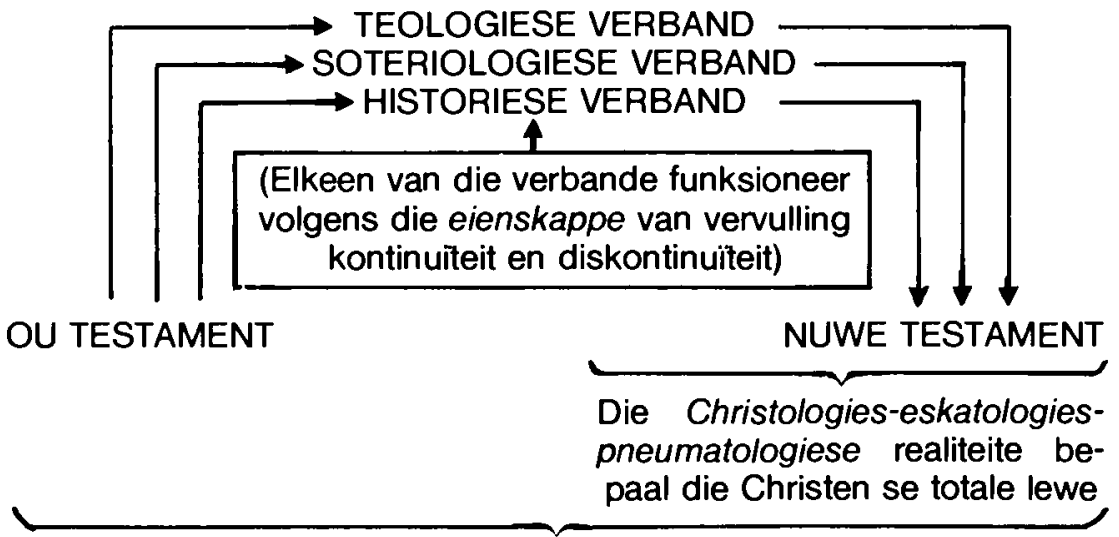

Hierdie verbande is moontlik omdat albei Testamente oor een God handel.

Dit wil dus voorkom asof die vroeë Christene oor die algemeen 'n totaliteitsbenadering gehad het. Die Ou Testament was nie iets wat afsonderlik op sy eie gestaan het nie, maar was opgeneem in 'n totaliteitsopset waarin elemente soos die Christologiese bepaaldheid, teologiese of soteriologiese verbande, elk'n bepaalde rol binne'n groter geheel gespeel het. Die Ou Testament as deel van die Christelike kanon kan dus alleen in die lig van die (Christelike) geheel geïnterpreteer word. So het dit vir die eerste Christene sin gemaak en so kan dit ook vir ons vandag sin maak.

\section{Die verhouding tussen die Ou en Nuwe Testament in heilshis- toriese perspektief vandag}

\subsection{Vandag se situasie langs dié van die vroeë kerk}

3.1.1 Ten spyte daarvan dat ons in die eeu van tegnologiese rewolusie leef, bevind ons onsself ten opsigte van Christus essensieel in dieselfde posisie as wat die geval met die vroeë Christene was. In terme van die heilsverloop in die geskiedenis is en bly die bepalende "Mitte" steeds Christus. In die tweeduisend jaar wat intussen verloop het, het geen 
bepalende heilsgebeurtenis addisioneel plaasgevind wat ons heilsituasie in beginsel of essensieel van die van die vroeë Christene skei of onderskei nie. Daarmee word die tweeduisend jaar se kerkgeskiedenis wat tussen vandag en die vroeë Christene lê, nie misgekyk nie. Daar word alleen gesê dat die tweeduisend jaar se kerkgeskiedenis aan die hand van dieselfde bepalende heilsgebeurtenis ontvou het en vandag nog ontvou.

Ons bevind onsself dus binne dieselfde geloofsrealiteit of tradisie as wat die geval met die vroeë Christene was. Ons glo in dieselfde God in wie hulle geglo het, soteriologies glo ons aan dieselfde Verlosser en verlossingsplan, teologies glo ons dat God op dieselfde wyse teenoor ons sal optree as wat dit uit die geskiedenis wat in die Skrif ontvou, aangetref word. Histories staan ons in 'n deurlopende tradisielyn met die vroeë Christene. Daar is dus sprake van 'n voortsetting of voortgaande realisering in ons situasie van die verbande wat in die vroeë kerk aanwesig was. Voortgaande realisering impliseer dat wat in hulle situasie ' $n$ realiteit was in ons situasie ook realiseer. Daar is nie nou skielik ander heilswaarhede wat ons situasie bepaal nie.

Tussen die Ou en Nuwe Testament bestaan daar byvoorbeeld die element van vervulling. Wat in die Ou Testament staan, verander tot volheid. Tussen ons situasie en die van die Nuwe Testament is daar nie sprake van vervulling nie. Die volheid van die tyd is nou daar soos wat dit in die tyd van die vroeë Christene daar was. Wat in die Nuwe Testament vervul is, hoef nie in ons situasie "nog voller" te word nie. Teologies en soteriologies verkeer ons dus in dieselfde situasie as die Nuwe-Testamentiese gemeente. Wat vir hulle op heilsvlak waar was, geld ook vir ons vandag.

Vir die integrasie van die Ou en die Nuwe Testament sou dit beteken dat ons vandag ook nog die verbande (met hul eienskappe) as hermeneutiese sleutel sou kon gebruik ten einde die Ou-Testamentiese materiaal verder te ontsluit. Hierdie gebruik van dieselfde hermeneutiese sleutel kom nie op 'n starre eksemplarisme neer nie, maar op die erkenning dat ons vandag nog deel aan dieselfde geloofsrealiteit met dieselfde geloofsdinamiek en -oortuigings as wat die geval met die eerste Christene was.

3.1.2 Indien hierdie benadering as ' $n$ hermeneutiese uitgangspunt dien, is dit duidelik dat die Ou Testament nie as ' $n$ "afsonderlike entiteit" teenoor die Christen van vandag te staan kom nie, maar deel vorm van ons Christelike geloofsrealiteit, wat ons natuurlik met die vroeë Christene deel. Von Rad stel dit onomwonde: "...for Christians the Old Testament only has meaning in so far as it refers to Christ and was able to speak in the light of Christ". ${ }^{41)}$ 
'n Belangrike implikasie van die feit dat die Ou Testament binne 'n geloofsrealiteit gelees word, is dat dit geïntegreerd binne daardie realiteit funksioneer. Christelike teoloë benader en lees tereg dan die Ou Testament binne hierdie geïntegreerde geheel. Frör brei volledig hieroor uit en kom tot die gevolgtrekking dat die Ou Testament vierkant binne die hele proses van God se handelinge met die mens staan en daarom "...nur vom Christuszeugnis des Neuen Testaments her recht verstanden werden kann". 42)

\subsection{Die hantering van die Ou Testament vandag}

3.2.1 Onttrek die Christen hom aan die geïntegreerde geloofsrealiteit in 'n poging om die Ou Testament sogenaamd "in sy eie reg" te lees, word die Ou Testament so buite sy Christelike konteks waarbinne dit (of ten minste dele daarvan) van die begin af vir Christene sin gemaak het, hanteer. Dit is wel moontlik om die Ou Testament so te lees, maar die posisie van die leser moet dan omskryf word. Hy lees die Bybel dan nie meer as Christenteoloog wat eksistensieel in die skadu van die kruis staan nie, maar as godsdiensfenomenoloog. Daar word (in isolasie?) in 'n stuk van die geskiedenis ingesny sonder om die bepalende realiteite wat daarna plaasgevind het, te verreken. Daarmee bevind die uitlêer homself ook buite die Christelike verklaringstradisie wat so oud as die Christendom self is. Immers, die feit dat die Ou Testament as Christelike kanon beskryf word, toon hoe die kerk die Ou Testament wil lees: "Sie will es nicht lesen als ein historisches Dokument der orientalischen Literaturgeschichte, Zeitgeschichte oder Frommigkeitsgeschichte". ${ }^{43)}$ Vir die vroeë Christene was die Ou Testament deel van hul geïntegreerde geloofsituasie waarin hulle hulself bevind het. Dit is ' $n$ situasie waarin ons vandag ook nog staan.

3.2.2 Indien die hermeneutiese vertrekpunt gehandhaaf word dat die $\mathrm{Ou}$ Testament 'n sinvolle plek binne die groter geheel van die Christelike realiteitservaring inneem, moet tegelyk erken word dat dit iets bydra tot die geheel, maar terselfdertyd nie geisoleerd buite die geheel behoort te funksioneer nie. Dit beteken dat die Ou Testament nie sy betekenis ontneem word wanneer dit binne ' $n$ Christelike konteks gelees word nie. Die Ou Testament in sy uniekheid staan eerder binne breër verbande wat met die koms van Christus 'n werklikheid geword het. Die Ou-Testamentiese gegewens pas dus in 'n nuwe perspektief in. So beweer Dodd dat die Nuwe Testament gewoonlik getrou aan die Ou Testament se algemene bedoeling gebly het, maar erken: "The transposition into a fresh situation involves a certain shift, nearly always an expansion, of the original scope of the passage". 44 ) 
Só gesien kan die Ou Testament dus "in sy eie konteks" en "na sy eie bedoeling" gelees word. Daarby moet dit nie blynie. Hierdie inligting moet verder teen die breër perspektief van die Nuwe Testament geinterpreteer word. Dit vind plaas in lyn met die reeds genoemde verbande met hul eienskappe. Deur die Ou Testament "in eie reg" te lees beteken onder andere om die teologiese of soteriologiese aansprake van daardie gedeelte na te gaan, soos dit in voor-Christelike Ou-Testamentiese perspektief na vore tree. Hierin kom die Ou Testament tot sy voile reg wat sigself betref, maar allermins wat sy posisie in die geheel van God se openbaring betref. Christus het gekom en daarom moet die interpretasie van die $\mathrm{Ou}$ Testament (in sigself) as ' $n$ verdere stap in die interpretasieproses, in die lig van die Nuwe-Testamentiese gebeure geplaas word. Dit belig verdere dimensies binne die Ou-Testamentiese gedeelte wat die boodskap van die Ou Testament "voller" maak, omdat dit binne 'n voller perspektief gelees word.

3.2.3 As in terme van "voller" en "nuwe perspektief" gepraat word, is dit duidelik dat daarmee nie gesê word dat Jesus verskuil lê agter elke vers in die Ou Testament nie - allermins. Dit sou immers uit' $n$ historiese perspektief beteken om Jesus te wil "laat kom" voor Hy regtig gekom het. Dit impliseer eerder dat die Ou Testament in eie reg met sy verskuildheid, vraagtekens en hoop gelees word, maar dat daarby nie gestop word nie. Die perspektief wat die Nuwe Testament werp op dieselfde problematiek wat in die betrokke Ou-Testamentiese gedeelte behandel word, moet ook verreken word ten einde dit werklik die "volle evangelie" te kan noem, of dit nou kontinu of diskontinu met die Ou-Testamentiese gebeure staan. Op dié wyse laat die Nuwe Testament nie alleen telkens die Ou Testament "helderder" skitter nie, maar plaas die Ou-Testamentiese gebeure ook telkens die Nuwe Testament in helderder perspektief.

Hieruit is dit dus duidelik dat die Ou Testament se tong nie uitgesny word sodat dit maar moet buikspreek soos die Nuwe Testament voorsê nie. Die eie selfstandige en funksionele plek van die Ou Testament word eerder erken. Dit beteken dat die Ou Testament nie 'n onnodige aanhangsel vir Christene is nie, maar dat dit op ' $n$ bepaalde manier ' $n$ bepaalde funksie in die geheel van die openbaringsgebeure vervul.

3.2.4 Tot dusver is daar klem gelê op die kontinuiteit wat daar tussen die huidige situasie en dié van die vroeë kerk bestaan. Daar bestaan egter ook elemente van diskontinuitteit veral wat die konkrete situasies van destyds en vandag betref, asook die wyse waarop daar interpretatief met die teks omgegaan word. Huidig word daar baie meer gereserveerd met allegorie omgegaan, terwyl die eksegete van destyds van histories-kritiese of mo- 
derne literatuurbenaderings nie eens gedroom het nie. Hierdie verskille lê egter meer op die vlak van die benadering van die tekste en kan nooit geïsoleerd staan van al die elemente wat in die geloofseenheid saamgesnoer is nie.

3.2.5 Kortom, wat dus in die lig van die situasie in die vroeë kerk voorgestaan word, is dat ons die Ou Testament in sy eie reg lees as deel van die boodskap van die Here aan sy kerk. Dit is egter maar die begin van die proses omdat die Ou-Testamentiese boodskap binne die konteks van 'n Christelike gemeente moet weerklink. Dieselfde God word gehoor, maar die heil waarna die Ou Testament maar net kon verwys, is nou gerealiseer; die verwagtings waarvan die Ou Testament vol is, is vervul; die dag van die Here het gekom.

Die teologiese, soteriologiese en historiese verbande met hul eienskappe van vervulling, diskontinuitteit en kontinuilteit wat die vroeë Christene die Ou-Testamentiese boodskap nuut laat verstaan het, bied ook vir ons vandag nog 'n sleutel tot die sinvolle integrasie van die $\mathrm{Ou}$ Testament in ons situasie.

Op dié wyse bied die Ou Testament dus 'n funksionele bydrae in die groter proses van die kommunikasie van die evangelie. Hoewel die $\mathrm{Ou}$ Testament as sodanig nie duidelik die Christelike evangelie in al sy detail bevat nie, funksioneer dit as deel van die groter Christelike boodskap. Vir die Christenteoloog kan die Ou Testament nie alleen staan nie, maar vorm dit deel van die bedding waaruit die Nuwe Testament gegroei het.

Skematies kan dit so voorgestel word:

\section{STAP 1: Lees die Ou Testament}
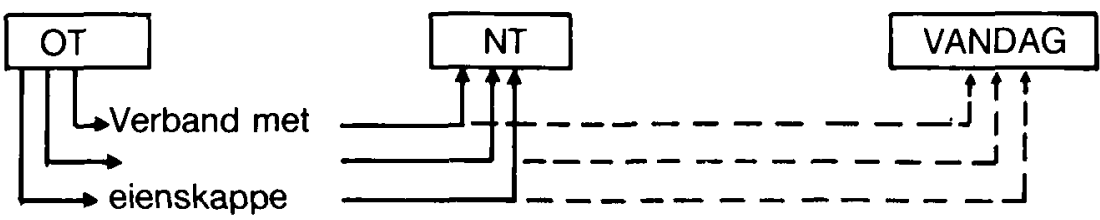

STAP 2: Plaas die Ou Testamentiese gegewens in die verrykende perspektief van STAP 3: Integreer al die gegewens hermeneuties as die boodskap vir vandag die Christus-gebeure volgens verbande en eienskappe

Dieselfde Christologiese-eskatologiespneumatologiese realiteit bepaal die Christene se lewens

76 DIE VERHOUDING TUSSEN OU EN NUWE TESTAMENT HEILSHISTORIES OORWEEG 


\section{Slot}

Nie die Ou of die Nuwe Testament staan of funksioneer alleen binne die Christelike konteks nie. Slegs in funksionele samehang kan die Testamente onderling in korrekte perspektief gelees word. So sal die Ou Testament nie gelees kan word asof daar nie 'n kruis en opstanding was nie en die Nuwe Testament nie asof dit tradisieloos uit die hemel geval het nie. Immers, die Christusgebeure vorm 'n brug van die Ou Testament na die Nuwe Testament, maar ook van die Nuwe Testament na die Ou Testament.

\section{NOTAS}

1. DL Baker, Two Testaments, one Bible, Leicester 1976, 19.

2. Vergelyk Baker, aw en in 'n mindere mate G F Hasel, New Testament Theology, Grand Rapids 1978, 171w, wat elk 'n oorsig bied.

3. Enkele name soos A A van Ruler, $\mathrm{K} \mathrm{H}$ Miskotte en $\mathrm{J} L$ McKenzie sou hier genoem kon word.

4. Dink maar aan Marcion of Harnack.

5. Von Rad en Cullmann lê byvoorbeeld klem op die heilsgeskiedenis, Westermann werk met"groot samehange" en F F Bruce met "dominante motiewe".

6. R Bultmann en in 'n mindere mate Baumgärtel kan hier as voorbeelde dien.

7. Op volledigheid kan nie aanspraak gemaak word nie. Daar gaan ook vanweé die aard van die onderwerp oorkoepelend met die Bybelse materiaal gewerk word - beklemtonings deur individuele skrywers gaan nie aandag ontvang nie. Gewoon uit die aanpak is dit duidelik dat daar van die veronderstelling uitgegaan word dat daar tog so'n mate van ooreenstemming tussen die Nuwe-Testamentiese skrywers bestaan dat 'n sistematiese aanpak soos wat hier gevolg word, sinvol gedoen kan word.

8. Vgl F S Malan, "The use of the Old Testament in 1 Corinthians", Neotestamentica vol 14 (1981), 137-170 se navorsingskonklusies in die verband. P Stuhlmacher, Vom Verstehen des Neuen Testaments, Göttingen 1979, 32-44 praat van die opname van die Ou Testamentiese tradisie in die Nuwe Testament as wesentlik deel van die Christendom wat juis die natuurlike tradisie-historiese voortgang van godsdienstige belewing waanvan die Ou Testament getuig, in die Nuwe Testament onderstreep.

9. U Luz \& R Smend, Gesetz, Mainz 1981, 140.

10. J Barr, The Bible in the modern world, London 1977, 166 baseer sy hele argument rondom die verhouding tussen die Testamente op die geloof in die verhouding tussen die God van Israel en Jesus: "The Christian faith stands equally upon the basis of the Old Testament and of the New or, more correctly, upon the basis of the God of Israel and of Jesus of Nazareth". W Eichrodt, Theology of the Old Testament, Philadelphia 1959, 2-6 stel dit selfs sterker. Hy baseer die eenheidsaanname tussen die twee Testamente op die feit dat, volgens albei Testamente, die koninkryk van God in hierdie wêreld "inbreek" en sê dan: "This is the unitive fact because it rests on the action of one and the same God in each case... This is why the central message of the New Testament leads us back to the testimony of God in the old covenant". J L McKenzie, A Theology of the Old Testament, London 1974, 28 sê: "The one whom Jesus called his father is the Yahweh of the Old Testament".

11. G von Rad, Old Testament Theology, vol 2 London 1977, 328-329 se bywoorbeeld: "The Old Testament was now read as a divine revelation which was the precursor of Christ's advent and was full of pointers towards the coming of the Lord; and this led to 
a completely new interpretation of the Old Testament... Everything is now referred to Christ".

12. Von Rad, aw, 332. D Guthrie, New Testament Theology, Leicester 1981, 960w en I H Eybers, “Eksegese van die Ou Testament by Qumran en in die Nuwe Testament" in W D Jonker (red), Hermeneutica, Pretoria 1970, 47 beskrył albei watter verskil die persoon van Jesus aan die inhoud van die eksegese van die Ou Testament maak.

13. $\mathrm{AB}$ du Toit en JH Roberts, Handleiding by die Nuwe Testament I, Pretoria 1977, 114.

14. Von Rad, aw, 332 noem dat die ad hoc aktualisasie van die Ou Testament in die Nuwe Testament dui op ' $n$ "general understanding of the relationship between the old and the new". C H Dodd, According to the Scriptures, London 1965 ontwikkel ' $n$ interessante teorie in die verband. Hy gaan naamlik die hantering van die Ou Testament in die Nuwe Testament na en kom tot die slotsom dat Paulus (asook die ander skrywers) "expressly bases his theology upon the kerugma as illuminated by the prophecies of the Old Testament" (135). Daar was volgens hom 'n hele "body of material" (127) wat gedeeltes uit die Ou Testament bevat het, asook 'n uiteensetting van hul belang vir en toepassing op die feite rondom die heilsgebeure van Christus. Hierdie vroeg-kerklike versamelingmateriaal het die substruktuur gevorm en reeds die vernaamste gedagtes bevat vir die ontwikkeling van die latere teologiese konstruksies deur Paulus en Johannes (127). Hierdie "Ou-Testamentiese materiaal" het binne 'n bepaalde historiese opvatting in die vroeë kerk gedy. Die geskiedenis speel af volgens 'n bepaalde plan en ontwerp wat God vir sy mense in gedagte het. Dit is nie strawwe predestinasie nie, maar eerder 'n "meesterplan" waarin die mens sy vryheid behou. "It is this pattern, disclosed 'in diverse parts and in diverse manners' in the past history of Israel, that the New Testament writers conceive to have been brought into full light in the events of the gospel story, which they interpret accordingly" (128).

15. Stuhlmacher, aw, 44.

16. Stuhlmacher, aw, 244.

17. J Bright, The authority of the Old Testament, London 1967, 198 toon in 'n opmerking die verhouding tussen die drie verbande aan: "The Old Testament's theology understands the whole course of Israel's history in terms of God's dealings with his people and his redemptive purpose for them and through them". Die soteriologiese en historiese verbande kan as element van die teologiese gesien word. Tog vervul al drie in die geheelopset so ' $n$ belangrike funksie dat dit ' $n$ mate van selfstandigheid verkry, sodat dit afsonderlik behandel moet word. Daarmee word die oorvleueling wat tussen die verbande bestaan nie ontken nie. Die historiese verband bied immers die bedding vir die teologiese en soteriologiese verbande. Die soteriologiese verband is weer bepalend vir wat as geskiedenis aangeteken word, terwyl hierdie geskiedenis binne die teologiese teenwoordigheid van God afspeel.

18. C Westermann, Theologie des Alten Testaments im Grundzügen, Göttingen 1978.

19. Vgl F F Bruce, This is that, Exeter 1968, 20v. Dodd, aw, 130, beweer dat die Christusgebeure "becomes the centre from which the whole history of the people of God, both backwards and forwards in time, is to be understood, and ultimately the history of all mankind".

20. S J PK Riekert, "Critical research and the one Christian canon comprising two Testaments", Neotestamentica vol 14 (1981), 27.

21. Skrifbewyse kan opgestapel word. Dink aan gedeeltes wat die pre-eksistensie van Christus beskryt en dus ' $n$ "plan van God" impliseer - Ef 1:4v of Jh 1. Uitdrukkings soos "die uur wat kom" in Johannes dui op die plan van God in die loop van die geskiedenis. Paulus praat etlike kere van die "geheimenis" wat God deur die Ou- 
Testamentiese era verborge gehou het, maar wat nou geopenbaar is, wat dui op God se geleidelike ontvouing van sy plan. Op teologiese terrein maak veral O Cullmann, Heil als Geschichte, Tübingen 1967, baie van die heilsgeskiedenis. Die geskiedenis is juis van belang omdat dit God se geskiedenis en plan met sy mense is. Cullmann, aw, 68 - praat van die voortgaande proses van heil waarin interpretasie van die hede ook in die lig van die verlede gemaak word. Dit gaan verder om voortgesette progressie: "Dann setzt die neutestamentliche progressive Ausbildung des heilsgeschichtlichen Kerygmas den im Alten Testament begonnen Prozess fort" (69). K Frör, Biblische Hermeneutik, München 1967,136 praat ook van die eenheidsproses: Dit is "die Einheit der Geschichte Gottes mit den Menschen, die die beiden Testamente miteinander verbindet.." Bright, aw, 199 sê: "By the claim of the Gospel itself the Testaments are inseparably bound to each other within the unity of a single redemptive history.."

22. C Westermann, Das Alte Testament und Jesus Christus, Stuttgart 1973, 51.

23. Von Rad, aw, 319.

24. KH Schelkle, Theology of the New Testament, vol 2 Minnesota 1973, 41 v. Dodd, aw, bespreek die moontlikheid ook volledig.

25. W Zimmerli, "Promise and fulfillment" in C Westermann (ed), Essays on Old Testament Hermeneutics, Virginia 1963, 115.

26. VglL Goppelt, Theologie des Neuen Testaments, Göttingen 1978, 376: "Paulus habe ... seine Theologie nicht aus der Schrift gewonnen, sondern sie nachtrăglich aus ihr begrundet". Kyk ook Malan, aw, 166. Schelkle, aw, 34-44 toon weer aan hoe Paulus en die vro kerk so cortuig was van die feit van die vervulling in Christus dat hulle dit vir opvoedkundige, missionêre en apologetiese doeleindes benut het.

27. Dodd, aw, 133.

28. A H van Zyl, "Die verhouding van die Ou en Nuwe Testament", in W D Jonker (red), Hermeneutica, Pretoria 1970, 17.

29. Eichrodt, aw, 26.

30. Frör, aw, 138.

31. Cullmann, aw, 85.

32. Bright, aw, 210v.

33. Bright, aw, 207.

34. R Bultmann, "Prophecy and fulfillment" in C Westermann (ed), Essays on Old Testament Hermeneutics, Virginia 1963, 73.

35. Van Zyl, aw, 7 .

36. Vgl A T Hanson, The New Testament interpretation of Scripture, London 1980, 3, wat van die Bybelskrywers sê: ".with strongly christocentric presuppositions ... they interpreted Scripture according to the technique which they had learned in Judaism"

37. EE Ellis, “How the New Testament uses the Old", in I H Marshall (ed), New Testament Interpretation, Exeter 1977, 202 praat van die Midrash wat as metode tot verhuidiging gebruik is. Die Ou Testament moes in die beleweniswêreld van die vroeê Christene "sin maak" Om dié doel te bereik is van eksegetiese metodes gebruik gemaak.

38. Ellis, aw, 211.

39. Ellis, aw, 212.

40. WS Vorster, "The function of the use of the Old Testament in Mark", Neotestamentica vol. $14(1981), 65$.

41. Von Rad, aw, 332.

42. Frör, aw, 138.

43. Frör, aw, 138.

44. Dodd, aw, 130. 